\title{
PSYCHOLOGY
}

\section{ФАКТОРИ СПРИЙМАННЯ ЧИТАЧАМИ ОБРАЗІВ АВТОРІВ ХУДОЖНІХ ТВОРІВ}

\author{
H. B. Сапригіна \\ Одеський національний університет імені I.I. Мечникова; дочент кафедри сочіальної і \\ прикладної психологї; кандидат філологічних наук; Україна
}

DOI: https://doi.org/10.31435/rsglobal_wos/30112019/6810

\section{ARTICLE INFO}

Received: 23 September 2019

Accepted: 16 November 2019

Published: 30 November 2019

\section{KEYWORDS}

image of the author, perception of readers \begin{abstract}
First the image of the author of works of art in the perception of readers by the method of semantic differential is studied together with the use a statistical analysis of competence levels of readers. Morality, stability, activity, creativity and aesthetics are the most important characteristics of writers and poets for their readers. The 3 levels of reading competence were identified, which corresponds to our classification, where we distinguish passive, active and creative readers.
\end{abstract}

Citation: Н. В. Сапригіна. (2019) Faktory Spryimannia Chytachamy Obraziv Avtoriv Khudozhnikh Tvoriv. International Academy Journal Web of Scholar. 11(41), Vol.2. doi: 10.31435/rsglobal_wos/30112019/6810

Copyright: (C) 2019 Н. В. Сапригіна. This is an open-access article distributed under the terms of the Creative Commons Attribution License (CC BY). The use, distribution or reproduction in other forums is permitted, provided the original author(s) or licensor are credited and that the original publication in this journal is cited, in accordance with accepted academic practice. No use, distribution or reproduction is permitted which does not comply with these terms.

Система «автор-текст-читач» привертає увагу як популярна схема комунікативних процесів і цікавить насамперед філологів. Між тим проблема комунікації міждисциплінарна $\mathrm{i}$ потребує психологічного вивчення. Саме психолог М.О. Рубакін [14] започаткував системний підхід до читацького сприймання текстів у взаємозв'язку 3 характером повідомлення. Продовжили його ідеї психолінгвісти Ю.О. Сорокін [17], .В. Сахарний [16] та інші. Знайомлячись 3 новими філологічними публікаціями щодо системи «автор-текст-читач», ми констатуємо, що у філологічних спеціальностях відсутні ефективні методики для вивчення особливостей читацького сприймання. В останніх публікаціях застосовується метод спостереження за інформацією у текстах письменників, яка налаштована на певні характеристики читачів (Олексій К.Б.[10], Павлюх Н. М. [12]). Бібліотекознавець В. Бородіна [1] вважає, що перспективним для вивчення особливостей читача $\epsilon$ метод семантичного диференціалу Ч.Осгуда [12] у різних модифікаціях. Але цим методом вивчались в основному читацькі оцінки творів та емоційна забарвленість їх сприйняття. Між тим відомо, що у спілкуванні людина спілкується не тільки з іншою людиною, але зі своїм образом цієї людини. Для вивчення сприймання та впливу художньої літератури, що $\epsilon$ ефектами віртуальної комунікації, ми звертаємося до категорії «образ автора».

Ця категорія була висунута у вітчизняному науковому колі літературознавцем В.В.Віноградовим [3], а у європейському просторі - літературознавцем В.Ізером [26]. В українському літературознавстві цю категорію розвивав Ю.Шерех, який поставив завдання розглядати «цілісний образ митця» і для цього використовувати мовознавчі, літературознавчі, історико-культурні та інші дані - «якнайширший вихід у позалінгвістичний простір» [22, с.148].

Категорія «образ автора» функціонує у системі «автор-текст-читач» (reader-response), яка вивчається у трьох напрямках - філософському (Гадамер Х.-Г. [4], Iser, W. [27], Бурмистрова И. В. [2] та ін.), літературознавчому (Лотман Ю.М. [7], Павлюх Н. М. [12], Петриченко I. [13], Эко У. [23], Яусс Х.Р. [24]). лінгвістичному (Геймбух Е. Ю. [5], Маленко О. О. [8] та ін.). У сучасних гуманітарних науках додаються напрямки - психологія 
3MI (Goldsmith, М. [25]) та психологія читання (Бородина В.А.[1], Черняк Ю. I. [20] та ін.). Часто спостерігаємо складність ввести конкретні дослідження до рамок певних наукових дисциплін у зв'язку з їх вираженою міждисциплінарністю (наприклад, Стул Т.Г. [18], Левчук Ю. [6], Хававчак О. [19], Шаповал М. [21] та ін.)., і найчастіше спостережувані явища відносяться до психологічних аспектів функціонування системи. Тобто система «автор-текстчитач» та її складові потребують психологічних досліджень. Психологія не мусить відвертатися від такого об'єкту як текст, бо тексти існують у психіці індивідів і породжують психологічні ефекти. Без участі людей тексти є мертвими, незрозумілими, як, наприклад критське лінійне письмо А, яке написано невідомою мовою. Психологічний напрямок вивчення системи «автортекст-читач» і її складових є об’єктом нашого наукового інтересу.

Категорію «образ автора» ми розглядаємо не як ознаки особистості автора у художньому тексті (наприклад, за думкою Е. Ю. Геймбух [2]), а як збірний образ автора у свідомості читачів. Ці образи письменників (поетів) у читацькій свідомості ми вивчаємо за допомогою семантичного диференціалу вперше, застосовуючи також методи статистичного аналізу.

Мета і завдання дослідження. Метою дослідження було виділити значущі для читачів якості авторів художніх творів та 3 їх допомогою отримати уявлення про збірні образи письменників у читацькому сприйнятті, а також знайти відмінності в сприйнятті образів авторів художніх творів різними читачами для підтвердження нашої концепції (Н.В.Сапригіна [15]) про існування різних рівнів комунікації та рівнів читацької активності в системі «автор - текст - читач».

Методом дослідження послугувала методика семантичного диференціалу Ч.Осгуда у модифікації Л.В.Матвєєвої [9], що підготована для вивчення сприймання телеглядачами образів телеведучих. 3 анкети, яка містила 120 шкал-питань, ми вилучили 20 питань, які не мали відношення до літературно-художньої діяльності.

Вибір методики пояснювався тим, що семантичний диференціал $є$ традиційним у дослідженнях $з$ психолінгвістики та адекватним поставленій нами меті. Кожне 3 питань містило пару антонімічних ознак, наприклад, «естетичний - антиестетичний». При цьому позитивні ознаки не завжди розташовувалися на початку шкали, щоб не чинити впливу на сприйняття випробуваного.

Деякі ознаки, наприклад «непрактичний - практичний», не передбачали обов'язково позитивної оцінки, а вносилися в анкету, щоб виявити знання або суб'єктивні уявлення піддослідних про особистості тих чи інших авторів.

Піддослідним давалася така інструкція (усно). Перший варіант. Виберіть одного 3 ваших улюблених авторів (письменник, поет, письменниця, поетеса). Охарактеризуйте вашого улюбленого автора за допомогою анкети.

Другий варіант. Ви можете вибрати автора, якого ви не любите. Охарактеризуйте його (ii) за допомогою анкети. Варіанти анкети вибирали самі випробувані.

Анкета для улюблених авторів починалася такою інструкцією: «Ваш улюблений письменник (поет). Вкажіть його (іi) ім'я. Оцініть його / іiі якості за ступенями: А - сильно виражена властивість, позначене лівим полюсом шкали; В - слабо виражена ця властивість; 0 не виражений ні лівий, ні правий полюс; С - слабко виражена властивість, позначена правим полюсом шкали; D - яскраво виражена ця властивість. Якщо Ви не знаєте або не впевнені, як оцінити ту чи іншу якість, ставте 0 ».

Для нелюбимих авторів давалася аналогічна інструкція і така сама анкета, але пропонувалося висловити (за бажанням), що саме не подобається в нелюбого автора.

Дані анкет узагальнювались у вигляді матриці, яка потім аналізувалася статистичними методами. Використовувалася програма Statistica 7.0.

Результати, отримані шляхом статистичного аналізу даних, зіставлялися з анкетними даними випробовуваних і даними, отриманими у безпосередньому спілкуванні.

Контингент випробуваних. Дані були отримані на підставі інтерв'ювання та анкетування наступних груп випробовуваних: студенти філологічного факультету Одеського національного університету імені I.I.Мечникова, а також студенти відділення психології Одеського національного університету. Вік випробуваних - 18-25 років. Кількість піддослідних - 242 особи, 3 них 11 чоловіків, решта жінки. Гендерні відмінності при проведенні дослідження не враховувалися. Всі указали, що російська мова $є$ для них рідною, для деяких дві рідні мови - українська та російська.

У дослідженні також брала участь особлива група випробовуваних творчих професій поетів, журналістів. До них ми додали групу науковців, які займались дослідженням творчості - літературознавців, психологів. Представники групи., яку ми позначили як «творча», в цілому займалися літературною і науковою творчістю: писали вірші, були авторами багатьох статей. Їх 
вік був 35-50 років. Загальна кількість випробовуваних в цій групі, яку ми назвали творчою, становила 71 особу. Студенти відповідали на питання, перебуваючи в групах, випробовувані творчої групи - в індивідуальному порядку.

Ще до початку дослідження багато читачів, яких ми вважали компетентними, відмовлялися від проведення дослідження. Наприклад, характерною $є$ така відповідь на лист 3 проханням відповісти на питання анкети. «Боюся, що я не зможу відповісти на надіслану Вами анкету. Головне, що я міг би відповісти по суті справи, не вписується у прямі відповіді на сформульоване в ній питання. Ну, припустимо, я багато читаю і художньої літератури - $\mathrm{i}$ для душі і для самоосвіти - $\mathrm{i}$ наукової (більше, втім, не цілком, а так, як читають довідники: більше для виявлення потрібної інформації, ніж для з'ясування концепції автора. Не бачу, як це пов'язано з моєю самооцінкою як автора або лектора, екскурсовода і т.п. і з моєї оцінкою слухачів або читачів. Вони бувають дуже різними: одні йдуть за мною, інші всіляко відпираються, і всіх під одну гребінку ніяк не візьмеш. Що ж стосується читачів, то в основному спостерігаю той феномен, який в "Чайці" Чехова описаний так: "Свою повість прочитав, а моїй навіть не розрізав"... » (Відкликання надіслав мистецтвознавець і перекладач художньої літератури).

Ідея про те, що не можна отримувати дані, пропонуючи всім одні й ті ж питання («стригти всіх під одну гребінку», читачі «бувають дуже різними»), звучала при мотивації відмови в основному в представників старшого покоління. Ця мотивація не була безпосередньо пов'язана зі складністю інструкції, необхідністю витратити час на заповнення анкети або з побоюванням розкриття особистих даних. Професійні психодіагности в таких випадках констатують, що особистість не бажає проникнення у свій внутрішній світ. Але творча група це той контингент, який постійно ділиться своїм внутрішнім світом, висловлюючи його в своїй творчості і відкриваючи публічно. Бачимо, що творчі особистості бажають контролювати і дозувати ступінь свого саморозкриття.

Проте, як вже було зазначено, нам вдалося переконати деяких представників старшої вікової групи і представників творчих професій взяти участь у дослідженні.

Аналіз результатів. Щодо особливостей читання наших респондентів були отримані наступні дані.

На питання «Скільки книг Ви прочитали за останні два місяці?» отримані відповіді: жодної - 17 осіб (7,02\%), 1 - 2 - 2 людини (0,83\%), 3 і більше - 223 людини $(92,15 \%)$.

Це говорить про те, що в опитуванні брала участь категорія осіб, яких ми умовно назвали «нечитачі», тобто вони не люблять читання художньої літератури. Таким чином, випробовувані поділилися на групи читачів і групу нечитачів.

На питання «3 якою метою Ви читаєте?» отримані такі відповіді: для відпочинку - 58 осіб $(23,97 \%)$, для роботи / навчання - 97 осіб (40,08\%), для саморозвитку - 85 осіб $(35,12 \%)$, інше - 2 особи $(0,83 \%)$

Відповіді на питання про коло читацьких інтересів показують, що інтереси наших респондентів не обмежуються корпусом художньої літератури. Інше - це книги, пов'язані з хобі, мемуарна література, науково-популярна.

На питання «Авторам якої статі Ви віддаєте перевагу?» Отримані відповіді: чоловічої статі - 65 осіб (26,86\%), жіночої статі - 5 осіб (2,07\%), не має значення - 172 людини (71,9\%).

Гендерні переваги - відповідь на питання «Книги яких авторів Ви переважно читаєте чоловіків або жінок?» для більшості наших респондентів не грають ролі. Однак для тих респондентів, які відповіли, що стать автора для них важлива, спостерігається закономірність: респонденти вважають за краще читати письменників чоловічої статі.

При вивченні сприйняття образу автора художнього твору звертає на себе увагу полярність точок зору. Одні і ті ж письменники були названі в якості улюблених і нелюбих.

Був названий широкий діапазон оцінюваних письменників, куди потрапили і класики, i представники сучасної літератури, в тому числі «авангардної» і «бульварної». Серед цих письменників мало повторюваних імен. Виняток - Сергій Єсенін. Його оцінювали 19 осіб.

Популярність поета можна пояснити кінофільмом про нього, який демонструвався на телеекранах в період проведення нами опитування. Крім того, в цьому фільмі була повідомлена сенсаційна звістка: слідчий Едуард Хлисталов (реальна особа), взявшись за розслідування обставин смерті Сергія Єсеніна, довів, що поет не наклав на себе руки, як нам повідомляли в офіційній біографії, а був убитий. Ці реальні факти і події укупі з доказами їх, справили сильне враження на тих, хто опинився з ними знайомими. Під знаком цієї сенсації до особистості 
Єсеніна було залучено сильну увагу читачів. Не в останню чергу була значущою та обставина, що роль Ссеніна зіграв популярний актор Сергій Безруков. Фахівці, знайомі зі спогадами про Єсеніна і фотографіями поета, стверджують, що цей образ не схожий. Однак розгорнута дискусія тільки підігріває читацький інтерес до поета.

Що стосується причин появи деяких негативних оцінок, їх можна пояснити почуттям протесту.

Саме воно штовхало наших респондентів оцінити Достоєвського, Льва Толстого, Пушкіна, Івана Франка і Тараса Шевченка як нелюбимих авторів (анонімність відповідей гарантувалася). Відносно цих письменників були і протилежні анкети, що описують цих авторів як улюблених (приблизно порівну). В даному випадку ці образи є культовими фігурами, знаками цінностей світу, етносів, нації. Протест проявляється, коли $з$ цих живих людей із складною долею створюють ідолів, спотворюючи і згладжуючи їх реальні риси, а іноді навіть вигадуючи їх, через що молодь не отримує справжнього уявлення про цих особистостей. Також молоді люди вважають, що шкільна та вузівська програма нав'язує культ цих письменників разом зі штучними тлумаченнями творчості. Через тиск чужих оцінок i офіційного культу молодим важко отримати справжнє власне враження про значення автора. Тому вони вважають за краще шукати авторів, які невідомі старшому поколінню, і знаходять улюблених авторів у потоці нової некласичної літератури.

Все ж ряд позитивних оцінок класиків і сам вибір класиків як об'єктів оцінювання вселяє надію, що цей розрив між представниками різних поколінь не такий великий і що для тих і інших існують загальні цінності культури.

Інша обставина, з якою ми зіткнулися при обробці даних, - це розкид оцінок. В оцінках не спостерігається одностайності. Наприклад, бали, які одна випробувана поставила Анні Ахматовій, показують індивідуальну характеристику образу поетеси читачкою. Ця характеристика суттєво відрізняється від тих, що описані іншими читачами $\mathrm{i}$, можливо, не відповідає розглянутим текстам поетеси.

Одна й та ж якість оцінюється і як позитивна, і як негативна, як властива даній особистості або не властива. Образи авторів характеризуються детально, докладно. Читачі виявилися в змозі відповісти на весь масив питань.

Розкид точок зору і детальність опису образів говорять про те, що читацьке сприйняття образу письменника тяжіє до індивідуальної своєрідності, унікальності, як і саме літературне мистецтво.

Ми зіткнулися 3 труднощами оцінювання, який саме опис літератора є близьким до істини, який - ні. Наша власна точка зору не повинна бути вирішальною у цьому питанні. Тому ми вдалися не до порівняння відповідей (дуже різних), а до самооцінки компетентності випробовуваних. В даному дослідженні вона проявилася в тому, що, згідно 3 інструкцією відповідь «не знаю» позначалася цифрою нуль. Тому кількість нулів у відповідях характеризувала самооцінку невпевненості (некомпетентності).

Відповіді були розподілені за кількістю нульових оцінок, які проставлялися випробуваними. Цей показник ми позначили як «індиферентність». Кількість нульових оцінок коливалася від 25 до відсутності нулів (крім одного винятку - 50 нулів). Чим більше нульових оцінок, тим нижче компетентність піддослідних. Максимум компетентності - відсутність нульових оцінок (індиферентність - 0).

Завдяки статистичному аналізу даних нам вдалося скласти картину сприймання читачами образів авторів художніх творів.

Групу випробуваних, яка оцінювала улюблених авторів, ми позначили як групу «а» (158 випробуваних), групу, яка оцінювала нелюбих авторів, - як групу «б» (84 випробуваних). У кожній групі підраховувалася кількість індиферентних (нульових) оцінок. Пропуски також оцінювалися як нульові оцінки.

У кожній групі за кількістю індиферентних відповідей, тобто ознакою самооцінки компетентності / некомпетентності, нами виділено три підгрупи читачів. Для групи «а»: 1a некомпетентні, 2a - малокомпетентні, 3а - компетентні. Аналогічно для групи «б»: 16 - некомпетентні, 26 - малокомпетентні, 36 - компетентні. Поділ підгруп проводився відповідно до значень терціль.

Чисельність підгруп виявилася наступна: 1а - 54 випробовуваних, 2a - 50, 3a - 54, 16 $28,26-30,36-26$.

Далі розраховувалася статистична значимість відмінностей між підгрупами за критерієм Манна-Уїтні. Статистично значущими вважалися значення критерію при $\mathrm{p}<0,01$ за причиною множинних порівнянь і необхідності введення поправки Бонфероні. 


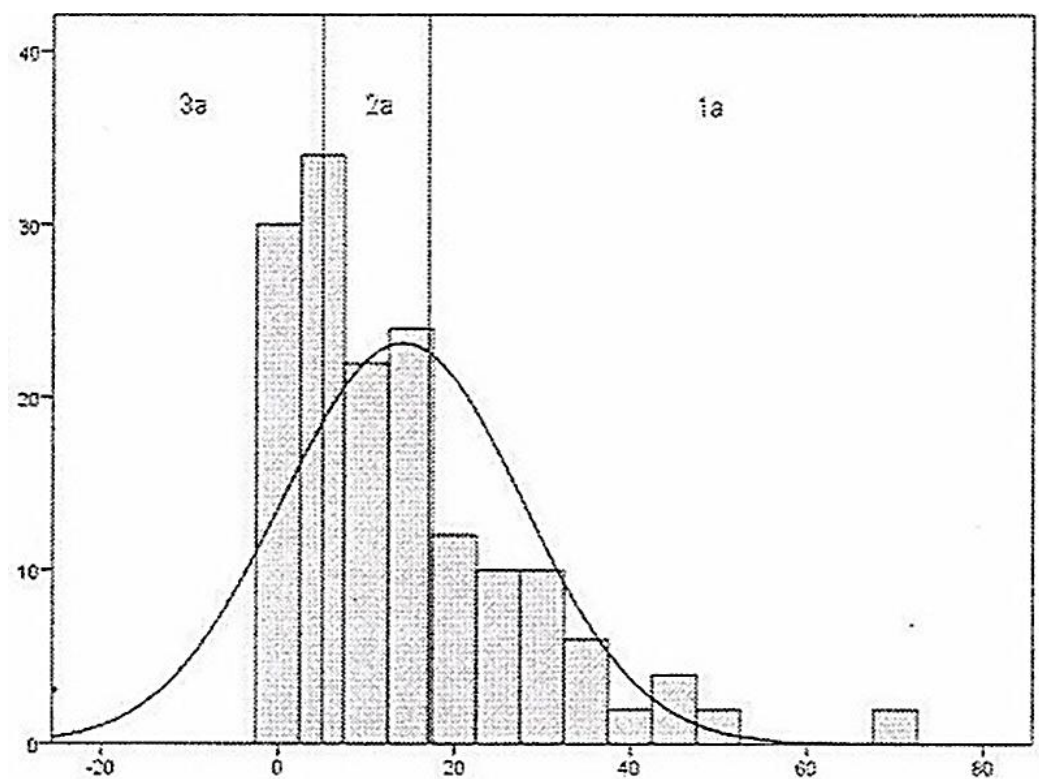

Рис.1. Розподіл кількості індиферентних оцінок щодо улюблених письменників. На осі хкількість індиферентних оцінок, на осі у - частота

В якості особливої думки одна випробувана, оцінюючи улюбленого поета Едуарда Асадова, поставила 50 нулів. Це означає, що вона майже нічого не знала про Асадова, а його вірші, швидше за все, чула від друзів. Не знала, можливо, і те, що цей поет - незрячий. Йому доводилося долати важкі життєві обставини. У цьому випадку ми бачимо мінімум когнітивних характеристик для опису свого уявлення про поета.

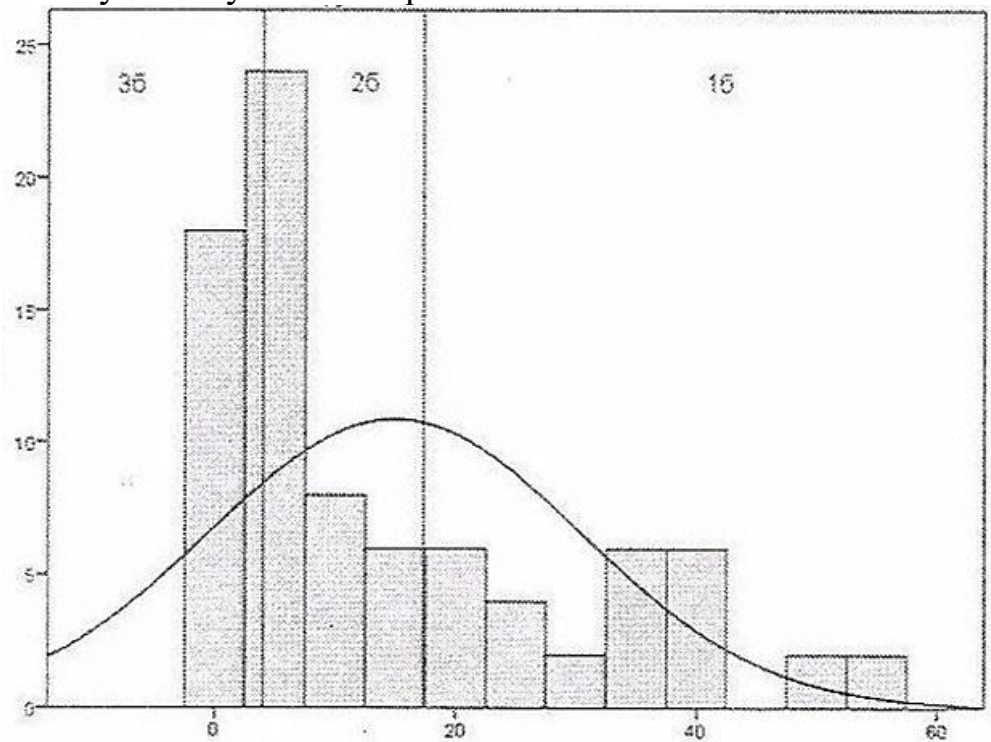

Рис. 2. Розподіл кількості індиферентних оцінок щодо нелюбимих письменників. На осі х кількість індиферентних оцінок, на осі у - частота

Всього в творчій групі, сформованій до початку дослідження, була 71 особа. За даними статистики, компетентна група склала 80 осіб. Статистична різниця між очікуваними даними (71 особа) і дійсними (80 осіб) становить 0,5657, і $є$ незначущою.

Таким чином, творча група, виділена до початку дослідження, і компетентна група, отримана в ході дослідження, в основному збіглися між собою. Тобто існує зближення між креативністю і компетентністю творчого читача.

Таким чином, наші теоретичні положення про те, що існують три основні групи читачів, які по-різному відносяться до текстів художньої літератури та їх авторів, знайшло підтвердження в емпіричному дослідженні. Один із критеріїв відмінності груп компетентність, тобто ступінь зменшення індиферентності.

Аналогічні групи виділяються і при дослідженні анкет про нелюбимих авторів. 
Серед улюблених письменників-класиків - Ахматова, Блок, Булгаков, Достоєвський, Чехов, Шекспір. Серед нелюбимих - Кафка, Маяковський. Серед сучасних улюблених авторів Вербер, Висоцький, Роулінг, Ошо, Толкієн, Ніка Турбіна. Серед сучасних нелюбимих - автори детективів Донцова і Мариніна. Одні і ті ж автори отримали характеристику улюблених i нелюбимих - Ахматова, Блок, Булгаков, Цвєтаєва. Таким чином, значимість автора в культурі не завжди сприяла винесенню йому позитивних оцінок.

Нами був також застосований метод факторного аналізу даних. Нашим завданням було виділення факторів, які є провідними конструктами, за якими читачі сприймають і оцінюють письменників.

В результаті факторного аналізу методом головних компонент 3 по-наступним обертанням за методом Varimax було виявлено п'ять факторів, що пояснюють 40,390\% загальної дисперсії даних. Критичним значенням факторного навантаження для включення прикметників в фактор було 0,500 за абсолютним значенням. В результаті нашого дослідження було виявлено п'ять наступних факторів, які ми позначили як «моральність», «стабільність», «активність», «креативність», «естетичність».

Нижче ми поміщаємо список факторів і шкали, що увійшли в кожен фактор, із зазначенням частки кожного фактора в загальній дисперсії.

Перший фактор «Моральність» описує 18,312\% загальної дисперсії і включає категорії:

чуйний 0,722 ; лагідний $-0,691$; добрий 0,675 ; демократичний 0,654 ; нехитрий $-0,653$; простодушний $-0,650$; доброзичливий 0,638 ; альтруїст 0,624 ; відкритий 0,613 ; добросердий 0,613 ; безкорисливий $-0,612$; моральний $-0,589$; дружній 0,573 ; приємний 0,558 ; чесний 0,555 ; тонкий $-0,515$; правдивий $-0,510$.

Другий фактор «Стабільність» описує 7,666\% загальної дисперсії і включає шкали: стриманий $-0,702$; скромний 0,693 ; делікатний 0,672 ; терплячий 0,657 ; порядний 0,583 ; врівноважений 0,572 ; об'єктивний 0,566 ; тактовний 0,551 ; організований 0,529 ; поважаючий 0,506 ; скутий $-0,508$; спокійний $-0,508$.

Третій фактор «Активність» описує 5,899\% загальної дисперсії і включає категорії: незалежний 0,602 ; вольовий 0,540 ; працьовитий 0,530 ; сильний 0,530 ; рішучий 0,523 ; активний 0,520 ; організатор 0,513 ; самостійний 0,509 .

Четвертий фактор «Креативність» описує 4,485\% загальної дисперсії і включає шкали: талановитий 0,607 ; глибокий $-0,713$; оригінальний $-0,655$; благородний $-0,607$; вдячний $-0,598$; яскравий $-0,598$; ввічливий $-0,565$; чуйний $-0,539$; панівний $-0,536$

П'ятий фактор «Естетичність» описує 4,028\% загальної дисперсії і включає категорії: витончений 0,627 ; незвичайний 0,557 ; естетичний 0,540 ; авторитетний 0,525 ; чарівний 0,516 ; артистичний 0,514 ; виразний 0,507 .

Перераховані якості описують узагальнений портрет ідеального письменника 3 точки зору читачів-випробовуваних.

В результаті факторного аналізу виявилося можливим побудувати такі факторні простори для сукупного образу наступних письменників - Ссеніна (19 анкет), Пушкіна (7 анкет), Достоєвського (7 анкет) Ахматової (4 анкети) . На підставі факторних просторів можна спостерігати, що Достоєвський представляється випробуваним найбільш моральним і найменш стабільним.

Самий естетичний - Пушкін, найбільш креативна - Ахматова (суб'єктивність думки!). Образи письменників на факторних просторах характеризуються своєрідністю, відмінністю від інших. Їх лінії не збігаються.

Виходячи $з$ показників індиферентності, можна бачити, що найбільш невідомими виявляються Е.Асадов, У.Шекспір, Ошо, Й.Бродський, найбільша обізнаність проявляється читачами щодо О. Островського, Ф.Тютчева, Льва Толстого, А.А.Фета, В.Хлебнікова.

Для загального уявлення про те, як співвідносяться між собою виявлені фактори, зобразимо їх на одному графіку (рис.3).

У поданні читачів Оскар Уайльд виявляється аморальним, але естетичним. Поетеса Ніка Турбіна, яка була піднесена на хвилю популярності в 10 років Євгеном Євтушенком i покінчила з собою в 27 років, не витримавши байдужості оточуючих, позначена як нестабільна i неактивна. Оцінки є суб'єктивними: Ошо виявляється неестетичним (з чим можна погодитися). Гьоте виявляється некреативним (і з цим погодитися не можна). 


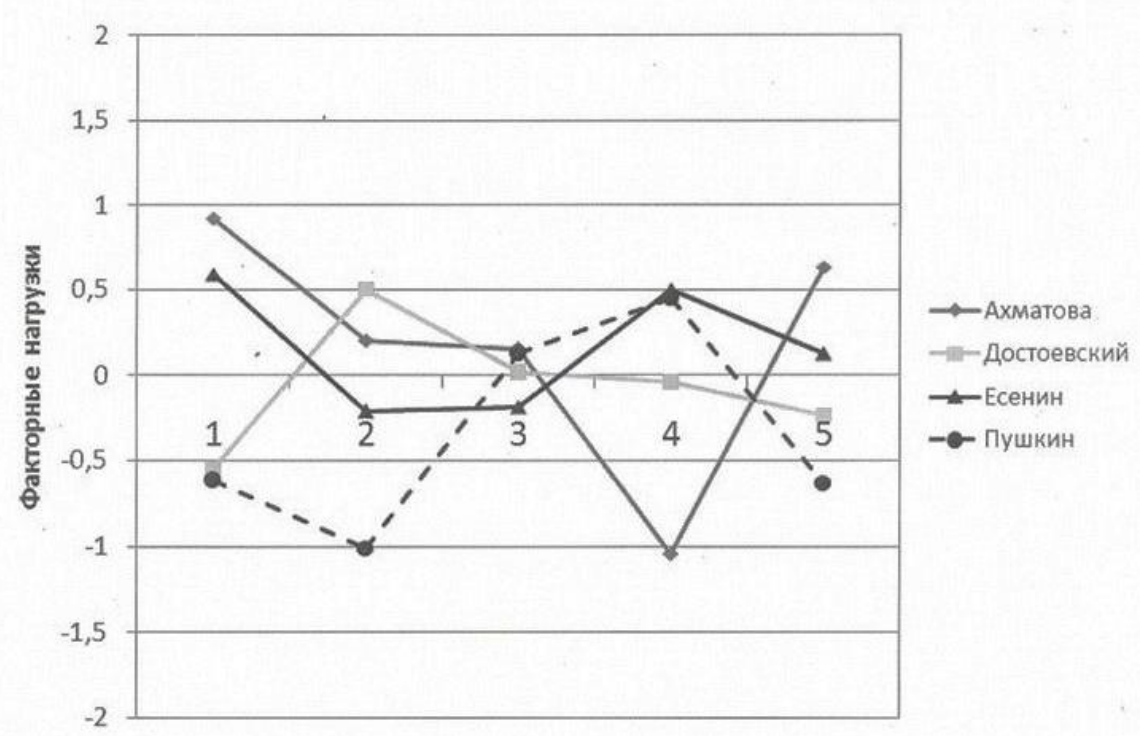

Рис. 3. Фактори якостей образів авторів художніх творів у сприйманні читачів:

1 -моральність, 2 - стабільність, 3 - активність, 4 - креативність, 5 -естетичність

В цілому можна констатувати, що за компетентністю читачі поділилися на 3 групи некомпетентні, малокомпетентні і компетентні. Це відповідає нашій класифікації рівнів читацької активності як пасивних, активних та творчих читачів. Група творчих читачів за складом в основному співпала з групою компетентних читачів, тобто творча активність випробуваних, про яку ми знали 3 попередніх анкет, бесід та особистого спілкування, поєднується 3 високою компетентністю у галузі знання художньої літератури та біографій письменників.

\section{ЛIТЕРАТУРА}

1. Бородина В. А. Психологические методы изучения читательского развития // Библиосфера. - 2008. №2. - C.18-23.

2. Бурмистрова И. В. Философская проблема "текст-читатель" : историческая динамика и интерпретации XX века : дисс ... канд.филос.наук : 09.00 .03 - философские науки, история философии - Ростов-на-Дону, 2013.- 150 с..

3. Виноградов В.В. Проблема образа автора в художественной литературе / В.В. Виноградов. Избранные труды. О языке художественной прозы. - М.: Наука, 1980. - 362 с.

4. Гадамер Х.-Г. Истина и метод: Основы филос. герменевтики: Пер. с нем./Общ. ред. и вступ. ст. Б. Н. Бессонова.-М.: Прогресс, 1988.

5. Геймбух Е. Ю. Образ автора как категория филологического анализа художественного текста. Автореф. дисс...канд.филол.наук. 10.02.10. - «русский язык». М., 1997.

6. Левчук Ю. Латеральне мислення як основа комунікативного ланцюга автор - жанр - читач // Наукові записки Національного університету "Острозька академія". Серія: Філологічна. - 2014. - Вип. 41. - С. 184-187.

7. Лотман Ю.М. Текст и структура аудитории // Лотман Ю.М. Избранные статьи: В 3 т. Таллин, 1992. T. 1. C. 161-167.

8. Маленко О. О. Творення й рецепція словесного образу в аспекті художньої ментальності автора читача // Лінгвістичні дослідження. - 2016. - Вип. 43.

9. Матвеева Л.В., Аникеева Т.Я., Молчанова Ю.В. Психология телевизионной коммуникации / - М.: РИП-Холдинг, 2004. -316 с.

10. Олексій К. Б. Діалогічність текстової комунікації: автор - текст - читач // Наукові праці Кам'янецьПодільського національного університету імені Івана Огієнка. Філологічні науки. - 2013. - Вип. 34. С. 234-237. 4. - Вип. 41. - С. 184-187.

11. Осгуд Ч. Приложение методики семантического дифференциала к исследованиям по эстетике и смежным проблемам / Ч.Осгуд, Дж.Суси, П.Танненбаум// Семиотика и искусствометрия: Сб.переводов / Сост. и ред. Ю.М.Лотман, В.М.Петров. - М.: Мир,1972.- С. 278 - 297.

12. Павлюх Н. М. Образ читача у новелах Е. Т. А. Гофмана / Н. М. Павлюх // Молодий вчений. - 2018. № 5(1). - C. 128-132.

13. Петриченко I. Проблема "автор-читач" у творчості Тараса Шевченка та в польській літературі першої половини XIX ст. // Шевченкознавчі студії. - 2008. - Вип. 11. - С. 260-269.

14. Рубакин Н. А. Психология читателя и книги: Краткое введение в библиологическую психологию / Н.А.Рубакин. - М.: Книга,1977.- 264 с. 
15. Сапригіна Н. В. Рівні адресата у комунікації читача та автора художнього тексту / Н.В. Сапригіна // Вісник Одеського національного університету. - Т. 11. - Вип. 11. Психологія. - 2006. - С. 45-51.

16. Сахарный Л. В. Введение в психолингвистику: Курс лекций / Л.В. Сахарный; Ленинград. гос. ун-т им. А. А Жданова. - Л.: Изд-во ЛГУ, 1989. - 180 с.

17. Сорокин Ю. А. Психолингвистические аспекты изучения текста / Ю.А. Сорокин; АН СССР. Ин-т языкознания; Отв. ред. А.И. Новиков. - М.: Наука, 1985. - 168 с.

18. Стул Т.Г. Методика обучения пониманию художественного текста на основе модели взаимодействия позиции автора и читателя — Дисс...канд.пед. наук : 13.00.02 : Тамбов, 2002. - 222 с.

19. Хававчак О. Наративний дискурс "Історії Русів" з точки зору комунікативної схеми: автор-текстчитач / О. Хававчак // Науковий вісник Ужгородського університету. Серія : Філологія. Соціальні комунікації. - 2011. - Вип. 25. - С. 122-126.

20. Черняк Ю. І. Літературний дискурс як комунікативний феномен / Ю. І. Черняк // Держава та регіони. Серія : Гуманітарні науки. - 2014. - № 4. - С. 16-20.

21. Шаповал М. Іншість Неди Нежданої: автор-персонаж і читач-персонаж як внутрішньотекстові проекції суб'єкта мовлення драматичного твору / М. Шаповал // Актуальні проблеми української літератури і фольклору. - 2010. - Вип. 15. - С. 19-27.

22. Шерех Ю. Третя сторожа: Література : Мистецтво / Ю. Шерех. - К. : Дніпро, 1993. - 590 с.

23. Эко У. Роль читателя. Исследования по семиотике текста; перев. с англ.и итал.С.Д.Серебряного. СПб. : Симпозиум, 2005. -502 с.

24. Яусс Х.Р. История литературы как провокация литературоведения // Новое литературное обозрение. 1995. №12. C. 34-84.

25. Goldsmith, M. Exploring the Author-Reader Relationship in Contemporary Speculative Fiction: The influence of author persona on readers in the era of the online 'author platform'. -Logos, Volume 27: Issue $1,2016 / 01 / 01$, p.31-44

26. Iser, W. The implied reader. Baltimore: The John Hopkins University Press , 1974

27. Iser, W. The act of reading: A theory of aesthetic response. London and Henley: The John Hopkins University Press, 1978. 